\title{
TWO ART EXHIBITIONS AS DIALOGIC EVENTS IN THE HISTORY OF CZECH-NORWEGIAN CULTURAL RELATIONS
}

\author{
MILUŠE JUŘíČKOVÁ
}

\begin{abstract}
The article analyses two art exhibitions in the context of Czech-Norwegian relations, presenting both the Czechoslovak book exhibition in Oslo (1937) and the Norwegian painting and applied art exhibition in Prague (1938) as important parts in a bilateral cultural dialogue. The promising initial communication in form of a mutual information exchange was soon disrupted by the beginning of World War II and post-war politics.
\end{abstract}

Keywords: Czech-Norwegian relations; cultural transfer; exhibition events; Olav Rytter; Czech literature; cultural diplomacy

Transnational cultural transfer is carried out on a large scale in a variety of communication forms, the most basic being translation events and reception processes of fiction and nonfiction literary texts. This article investigates some significant communication mechanisms in two art exhibitions, understood and denoted as representative performances of two countries in a concrete period, in the years 1937-1938.

The Czech-Norwegian relationship can be characterised as asymetrical in a particular aspect: the number of translated texts translated from Norwegian into Czech in the last 150 years has been several times higher than those translated from Czech into Norwegian (Kilsti 2010,258). The general interest in mutual cultural exchange has also been distinctly greater on the Czech side, taking into account the quantity of epitexts of various genres, such as book reviews and literary critics texts. The complex reasons for this imbalance are beyond the scope of this article. In spite of this it is essential to show that a unique, time-specific, and rather promising period existed in Czech-Norwegian efforts and interests in which the intercommunication was balanced. This dynamic period took place in the late 1930s after a bilateral agreement was signed in the field of culture. Because of the unstable conditions in Europe due to the threat from Germany, the bilateral cultural development soon broke down and was transformed during World War II. After 1945, the international balance of power essentially shifted, with Norway and Czechoslovakia at two separate sides of the Iron Curtain situated in opposing political systems. These circumstances led to the end of these types of communication events in the years that followed. 
In 1936, a bilateral cultural agreement was signed between the governments of Norway and Czechoslovakia, concerning a strategy for concrete cultural events supporting essential mutual recognition and understanding. The first arranged event was the exhibition of Czechoslovak books (Den tsjekkoslovakiske bok) which took place in Oslo in 1937, focused on the presentation of Czech literary history and book-design. In response, a representative exhibition of Norwegian painting and applied arts (Tisíc let norského výtvarného díla) was arranged in Prague a year later. The two exhibition events were surrounded by accompanying texts, including catalogues, information boards, interviews and newspaper articles in both languages, bringing a varied semiotic dimension to the communication frame.

In April 1937, the Czechoslovak government (Prime Minister Milan Hodža) arranged a representative exhibition, "The Czechoslovak Book" at the Handicraft Museum (Kunstindustrimuseet) in Oslo. The essence of the exhibition management attached with the exponent focusing on book design in combination with various forms of commentary such as illustrated catalogue as well as a supporting programme of lectures and press media. The structure of the exhibition was created by following the pattern of historical eras, beginning with the oldest manuscripts presented in form of photographs as well as precious medieval print originals to modern book design exemplars.

An evaluation of a dialogic exchange depends on the absorption capacity of the receiver of the information (Tondl 1997, 16); the limits of the information and value transfer are determined by the language and cultural competency of the audience. To strengthen the attention for the receivers, the Czech organisers produced a polysemiotic message (Tondl 1996, 223), investing energy in the process of presentation and interpretation of the exhibited book design artefacts as well as in the Czech literary history narrative line, especially in the mirror of the catalogue text. The catalogue text was not written by any representative Czech authority and then translated from Czech to Norwegian, but it was originally created in Norwegian by Olav Rytter.

The sender, in this case the supporters and creators of the exhibition, is concerned about being understood to the fully extent, and therefore seeks the appropriate methods to awaken the anticipated echo from the receiver. In this context, it should be emphasised that the opening ceremony was attended by Czechoslovak representatives - by Vladimír Kučera, a diplomat stationed in Stockholm also serving Norway, and by the diplomatic attaché Dr. Emil Walter, a reputable translator from Norwegian, Swedish, and Old-Norse. On this occasion, Albert Pražák, a professor from Charles University, arrived in Oslo and gave the opening lecture in the University Hall. The presence of professor Halvdan Koht, a foreign minister in the government of Johan Nygaardsvold (Det norske Arbeiderparti), also signalled the international significance of the event. The exhibition aroused attention in the Norwegian daily press, including Aftenposten, Dagsavisen, and Arbeiderbladet.

The main impetus for the successful accomplishment of the event was provided by the Norwegian scholar, linguist, translator, and journalist Olav Rytter, who had an excellent knowledge of Czech language, history, and culture. Rytter studied in Prague from 1934 to 1935 and succeeded in connecting with the leaders of Czechoslovak politics and culture 
during his stay. The former Czechoslovak President Thomas Garrigue Masaryk was also well informed about the Oslo-event, because Vladimír Kučera was a long-time member of the intimate intellectual circle around Masaryk, as was Karel Čapek - the best known and accomplished author from Czechoslovakia at the Oslo exhibition. Karel Čapek himself had visited Norway in 1936, on his legendary journey to the North. Olav Rytter wrote the first Norwegian text about Čapek's work, published in the magazine Syn og Segn, with following opening:

Ingen annan samtidig tsjekkisk diktar gaar so intenst upp i lagnaden aat folket sitt, men som ingen annan lever han óg igjenom, gruvlande og granskande den aalmenneeuropeiska kulturkrisa av i dag. Dette gjeld Karel Capek tvifeld interesse: Han er eit full-lødig uttrykk for tsjekkisk aand i dag, og han er ein av dei som er med og gjev det litterære Europa sitt andlet (Rytter 1935, 289).

Karel Čapek had been known in Scandinavia primarily from several Swedish translations, but in the theatre season 1937-38 Čapek's dramas were introduced to the Norwegian stage: The White Plague (Den hvite pesten) in Oslo and The Insect Play (Insektliv) in Bergen. In fact, Norwegian audiences had first encountered Čapek as early as 1921, sixteen years before the book-exhibition in Oslo, coincidentally in the same year that Norway and Czechoslovakia established their first official diplomatic relations. The theatre event then was R.U.R. at the Norwegian Theater (Det Norske Teatret) with the subtitle "Machine Man" (Maskinmenneskje), the Norwegian version came by way of English, the English translation from Paul Selver and Nigel Playfair (Landro 1995, 8) was used as a foundation for many other European translations.

The author of the exhibition catalogue text, Olav Rytter, worked as a journalist for the $\mathrm{BBC}$ in London during the Nazi occupation and later as a diplomat at the UN, but he remained a unique mediator for Czech literature in Norway. His exhibition catalogue text had over 50 entries, and was the first extensive, general overview of Czech literary history written in Norwegian. It included such names as Petr Chelčický, Bohuslav Balbín, Karel Hynek Mácha, Božena Němcová, Julius Zeyer, Alois Jirásek, Josef Hora and many others. The presentation incorporated also Slovak writers from the 19th and 20th century. The second part of the catalogue contained short samples and quotes from the historical Czech figures through thousand years - from the church reformer Jan Hus to the historian František Palacký up to the contemporary literary critic František Xaver Šalda.

The intention of the book exhibition event in Oslo was to show that literature is an essential bond and pillar of national identity, especially considering the difficult fate of small languages in the European context. The implied call for similarity, or perhaps parallelity, of the two respective countries is evident, especially considering their early historical achievements, followed by the medieval loss of independence to powerfull neighbours, and the long struggle towards national autonomy, culminating with a national breakthrough in the 19th century and the foundation of a modern democratic state in the 20th century. These aspects are noted in an implicit way; the catalogue opens with respectful words for the national efforts of the Czechs:

På samme måten som den tsjekkoslovakiske republikken er ei opattnying av gammal politisk sjølstende, byggjer den tsjekkoslovakiske litteraturen av i dag på tradisjonar som 
går attende til langt ned i millomalderen. Den tsjekkoslovakiske litteraturen har vakse fram i nær sammenheng med den historiske lagnaden åt det tsjekkoslovakiske folket, han gjev eit spegelbilete av den historiske utviklinga gjennom nasjonal vokster, nedfall og atterreising mesta tusen år (Rytter 1937, 6)

The collection of verbal signs in this statement meets the dimension of the nonverbal signs of the exhibition event. The intersemiotic aspects (Tondl 1996, 223) are also present in Emil Walter's programmatic words from a newspaper profile interview: "We are very interested in strengthening the dialogue with our well-known and beloved partner" (Aftenposten 9 April 1937). This is an obvious hint at the amount and popularity of Norwegian literature translated into Czech, which reached a new peak in the 1930s. The newcomers published in this period were: Sigrid Undset with books every year through various publishing houses, Olav Duun with the complete Juvikfolket (The People of Juvik), a six-part series, Sigurd Hoel and Tarjei Vesaas with their first novels, and many other Norwegian authors (Kadečková and Vrbová 1996). Surprisingly, the Norwegian interviewer also asked about „German literature from Prague”, being obviously well informed about the actual situation in Central Europe, and referring to the increasing number of refugees from Nazi Germany. Emil Walter reacted to this sensitive issue by responding immediately with an anecdote saying that when Karel Čapek was informed of his own repeated nomination for Nobel Prize in literature, he had reacted somewhat sarcastically: "If I do not get the prize, never mind - luckily we have another Czechoslovak author who already got the Nobel Prize - his name is Thomas Mann." (the Mann brothers and their families were awarded Czech citizenship in 1936). But the tone of the conversation remained earnest - Emil Walter afterwards mentioned the line of Czech religious and political emigrants through history, primarily Jan Ámos Komenskýs exile in the 17 th century. Nobody, least Walter himself, could have anticipated that he himself would spend the rest of his life after 1948 in political exile.

In spite of the informative content of the exhibitions, their character was rather performative, their effect was meant to be a contribution to a durable cooperative partnership in a democratic Europe. This performative target could not be achieved due to the complex situation, which was worsening daily in autumn 1938. The historical circumstances during the second exhibition in Prague, only eighteen months later, could hardly have been more contrasting in comparison with the Oslo event. The situation in the so called "Second Czecho-Slovak Republic", which existed between the Munich Agreement 30 September 1938 and the Nazi invasion 15 March 1939, was totally overshadowed by the general conviction of betrayal by Great Britain and France. Czechoslovakia had to deal economically and mentally with the increasing refugee problem of Czech people as well as Germans (primarily social democrats) evacuated from the Sudetenland border areas, and with the Austrian Jews on the run.

The exhibition in Prague, titled “Tisíc let norského výtvarného díla (Umělecký průmysl - knižní umění - architektura - lidové umění)”, "A Thousand Years of Norwegian Fine and Applied Arts (Handicraft - Book design - Architecture - Folk art)", was arranged at the Museum of Decorative Arts (Uměleckoprůmyslové museum) from 
December 1938 to January 1939 under the auspices of president JUDr. Emil Hácha and H.M. Crown Prince Olav. On this special occasion two commitees were established: a ministerial presidium and an honorary committee, where both countries were represented through very interesting individuals. In addition to the ministers, this included professor Arnošt Kraus, the founder of modern Scandinavian studies at Charles University (Kraus died in Theresienstadt in 1943), senator Františka Plamínková (she was executed for her resistance activities in 1942), Niels Hjemtveit (under Nazi occupation, a member of Norwegian government in exile in London), publisher Harald Grieg (a political prisoner at Grini detention camp during the war) and diplomat Niels Christian Ditleff (later supporting the Nansen-aid activities in 1939 and organizing the White Buses in 1945), as well as other figures from politics, economy, education, and culture.

The confusing and chaotic position of Czechoslovakia in the international context was standing central in the international press, also in Norwegian newspapers. In 1938, several Norwegian journalists and correspondents were sent to Central Europe to gather authentic reports on the atmosphere among the Czech population. During the summer of 1938, for example, Sigurd Evensmo was active as a correspondent for „Arbeidernes Pressekontor" in Prague. Another famous Norwegian author, Torolf Elster, described his own Czech experience in the analytic book Tsjekkoslovakia (1938); three years later before he had to escape to Sweden - his novel Historien om Gottlob inspired by opinions of Prague, was published. The Art Museum director Eivind Stenersen Engelstad, a member of the Norwegian delegation, and one of the catalogue authors, showed deep interest and empathy for the actual situation in Central Europe:

Selv om landet i det ytre er rolig, har Münchnerdagene etterlatt et dypt og ulegelig sår i alle tsjekkoslovakernes hjerter. De må snakke om det, fordi det piner hvert enkelt menneske, hvert lite medlem av en stor nasjon. [...] Vi kom i kontakt med mennesker av alle samfunnslag, overalt den samme hjertelighet, den samme interesse for og merkelige kjennskap om vårt land, og overalt og hos alle en dyp og personlig sorg over den skjebne deres fedreland hadde lidt i høst (Aftenposten 27 December 1938, 5).

The Czech catalogue with over 40 entries, translated from Norwegian into Czech by Dr. Oldřich Heidrich, contained four overview studies on book-design, historic and modern architecture, weaving and dyeing art, and even the art of the Viking Age. The annex includes the list of participating artists, as well as 26 black-and-white photographs of some exhibition artefacts.

Who were the featured artists in the Norwegian collection in Prague? The best known, Edvard Munch, had already had a separate exhibition in Prague in 1905, a unique event that had completely changed the shape of Czech modern painting history because of Munch's unforgettable imprint (Urban 2006, 20). In 1938, Munch was represented by only one book cover (Jens Riis: Edvard Munch og hans samtid), accompanied by Olaf Gulbransson, Per Krogh, Erik Werenskiold, Gustav Vigeland, Gerhard Munthe and many others, including Hugo Louis Mohr (correct spelling: Lous). In the years 1935-1949, Mohr was engaged as the decorator of the Oslo cathedral ceiling. In the Prague catalogue also "Fridtjof" Nansen is mentioned, but this name is likely an error, meant to refer to Fridtjof's son Odd Nansen, who was among the artists, as a painter and cartoonist, in addition to being an architect. 
The echo of the Norwegian exhibition is to be found in Lidove noviny, the liberal daily Czechoslovak newspaper, with rather brief informative articles, during December 1938. On 25 December, in the middle of the exhibition period, Karel Capek died. The premature death of an author who was the symbol of the independent Czechoslovak Republic, was one in a sequence that contributed to an essential change in the social atmosphere in Prague and the whole country. The participation in a cultural dialogue lacked energy and relevance, primarily on the Czech side. The external circumstances pushed the cultural issue out of focus, and the bilateral dialogue was in fact broken off.

There is no doubt that in the period from 1937 to 1938, Norway and Czechoslovakia increased their special views on each other's culture; the proclaimed goal was to reach a new level of mutuality. In addition, a series of international meetings were arranged. In July 1937, the ninth congress of Women's International League for Peace and Freedom was held in Luhačovice, attended by the leaders of the Norwegian section, Marie Lous Mohr and Sigrid Helliesen Lund, both active members in the organization Nansen-aid. In June 1938, the XVI. International congress of PEN clubs was arranged in Prague, and included several authors from Scandinavia, such as the Norwegian writer Lars Berg (Tršková 2020, 17).

On the brink of war, in February and March 1939, Odd Nansen, his wife Kari, and the Nansen-aid organization secretary Tove Filseth, spent several weeks in Prague and succeeded in organising transports to Norway for hundreds of Czechoslovak citizens, adults and children (Ellingsen 2015, 119-120). This initiative from Norway, saving Czech and Slovak lives, is still not as publicly known and acknowledged as it deserves. The Nansen-aid humanitarian affair lies outside the scope of a literature history study; yet this unique and almost forgotten action is clearly within the borders of mutual communication between Czech and Norwegian cultures in the 20th century.

The cultural issues described here should have signalled the opening acknowledgement of the freshly signed bilateral contract between Czechoslovakia and Norway. The contract should have brought the cooperation to a qualitatively high level, including awarding scholarships for candidates from both countries. It is interesting that one of the scholarship recipients in 1938 was the Czech poet František Branislav. The result of his study stay in Norway was the translation of Bjørn Rongen's novel Nettenes natt, published in Czech in 1941 as Noc všech nocí (Kadečková and Vrbová 1996). The reception of this moving testimony about ethical chalenges to the Norwegian identity was completely overshadowed by the ongoing tragic war situation in Central Europe.

The non-verbal dimension of the cultural dialogue, in the form of two art exhibitions, and the verbal dimension through the related paratexts succeeded in prospectively establishing an interesting situation in Czech-Norwegian relations. The intersemiotic dialogue was not only descriptive and informative, but also performative in the sense „implementing a new dialogue universe" (Tondl 1996, 187). The Norwegian-Czech attempts to seek near mutuality in the field of culture, both in 1937 and 1938, were evidently meant by the organisers and creators as an innovative communication act, yet owing to the external political conditions, this attempt was destroyed by World War II and by the communist 
coup in Czechoslovakia 1948. The communication gap between the Czech and Norwegian cultural universes remained in place until 1989 and has not yet been fully closed.

\section{BIBLIOGRAPHY}

Ellingsen, Anne. Odd Nansen: Arvtageren. Oslo: Historie \& Kultur, 2015.

Engelstad, Eivind S. „Inntrykk fra Tsjekkoslovakia i dag.“ Aftenposten 27. 12. 1938: 5.

Kadečková, Helena, and Jarka Vrbová. Bibliografi over norsk litteratur oversatt til tsjekkisk. Jinočany: $\mathrm{H}$ \& $\mathrm{H}, 1993$.

Kilsti, Kristin. „En asymmetrisk relasjon (en komparativ litterær kommentar).“ (Norsk inspirasjon: samfunnskultur i tsjekkisk-norsk dialog). Prostor, společensko-kulturní revue, XXVII (2010), nr 3-4: $258-260$.

Landro, Jan H. „Karel Čapek“. Hefte til Salamanderkrigen i serien Århundrets Bibliotek, De norske Bokklubbene 1995.

Rytter, Olav. „Karel Capek. Ein tsjekkisk diktar“, Syn og Segn 1935/41: 289-301.

Rytter, Olav. Den tsjekkoslovakiske bok. Kunstindustrimuseet i Oslo, catalogue, 1937.

Tisíc let norského výtvarného díla: Umělecký průmysl - knižní umění - architektura - lidové umění. Katalog. Praha: Umělecko-průmyslové museum, 1938.

Tondl, Ladislav. Dialog: sémiotické rozměry a rozhraní dialogu. Praha: Filosofia, 1997.

Tondl, Ladislav. Mezi epistemologií a sémiotikou: deset studií o vztazích poznání a porozumèní významu. Praha: Filosofia, 1996.

Tršková, Ivana. Krisen i Tsjekkoslovakia i 1938 sett av tre norske forfattere: Lars Berg, Sigurd Evensmo og Niels J. Mürer [online]. Brno, 2020 [cit. 2021-04-02]. https://is.muni.cz/th/u4zep/. Master's thesis. Masarykova univerzita, Filozofická fakulta.

Urban, Otto M., Jarka Vrbová, and Tomáš Vrba. Edvard Munch. Být sám. Ohlasy, deníky, obrazy. Praha: Arbor Vitae, 2008.

„Utstilling åpnet.“ Aftenposten 9. April 1937: 6.

Miluše Juřičková

Masaryk University in Brno

jurickov@phil.muni.cz 